\title{
Localization of denitrification genes on the chromosomal map of Pseudomonas aeruginosa
}

\author{
Kai-Uwe Vollack, ${ }^{1}$ Jun Xie, ${ }^{1}$ Elisabeth Härtig, ${ }^{1}$ Ute Römling ${ }^{2} \dagger$ \\ and Walter G. Zumft ${ }^{1}$
}

Author for correspondence: Walter G. Zumft. Fax: +497216084290.

1 Lehrstuhl für

Mikrobiologie, Universität

Fridericiana, D-76128

Karlsruhe, Germany

2 Karolinska Institutet, MTC, Department of

Bacteriology, Box 280,

Stockholm, Sweden

\begin{abstract}
Cleavage of chromosomal DNA from Pseudomonas aeruginosa PAO by Spel and DpnI has been used together with PFGE and Southern hybridization to establish the map location of the following principal denitrification genes: narGH (encoding the large and small subunits of respiratory nitrate reductase), nirs (cytochrome-cd, nitrite reductase), nirE (uroporphyrinogen-III methyltransferase for haem $d_{1}$ biosynthesis), norCB (nitric-oxide reductase complex), nosZ (nitrous-oxide reductase) and nosA (an outer-membrane protein and OprC homologue). The study also included several genes related to anaerobic or microaerophilic metabolism: napA (encoding the catalytic subunit of the periplasmic nitrate reductase), ccoN (catalytic subunit of the cytochrome-cbb ${ }_{3}$ oxidase), hemN (oxygen-independent coproporphyrinogen-III oxidase), an fnr-like regulatory gene, and azu and $f d x A$ (electron carriers azurin and ferredoxin, respectively). Genes necessary for denitrification are concentrated at $\mathbf{2 0}$ to $\mathbf{3 6} \mathrm{min}$ on the $P$. aeruginosa chromosome, where they form three separate loci, the nir-nor, nar and nos gene clusters. Genomic DNA of Pseudomonas stutzeri ZoBell was also subjected to Spel restriction and Southern analysis to assign denitrification genes to individual fragments. A homologue of nosA encoding a putative component of the Cu-processing apparatus for nitrous-oxide reductase was identified. In both $P$. aeruginosa and $P$. stutzeri there is evidence for the linkage of anr (fnrA) with hemN and ccoN; and for the presence of a napA gene.
\end{abstract}

Keywords: Pseudomonas aeruginosa chromosome, denitrification, Pseudomonas stutzeri

\section{INTRODUCTION}

The ability to denitrify nitrate to dinitrogen under anaerobic conditions is widespread among the pseudomonads. The most detailed chromosomal map of a bacterium capable of complete denitrification is currently that of Pseudomonas aeruginosa $\mathrm{PAO}$, which comprises close to 200 identified markers (Holloway et al., 1994; Liao et al., 1996). Among them are about a dozen related to anaerobic nitrate respiration and denitrification. Information on the location of denitrification genes was first sought for $P$. aeruginosa by conjugationaland transductionalmapping (vanHartingsveldt \& Stouthamer, 1973; Jeter et al., 1984). An important outcome of the early genetic analysis was the finding that $P$. aeruginosa possesses distinct gene sets

\footnotetext{
† Present address: Klinische Forschergruppe, OE 4350, Medizinische Hochschule, D-30623 Hannover, Germany.
}

encoding the respiratory (nar) and the assimilatory (nas) nitrate reductase systems (Sias et al., 1980), which is now assumed to be a rule for nitrate-assimilating denitrifiers. The distinct genetic basis for the respiratory and assimilatory process is manifest in different regulatory responses to oxygen and ammonia.

A total of about 50 genes have been identified to date in various denitrifying bacteria, about 30 of them in the genus Pseudomonas. The genes identified comprise the structural information for the nitrogen oxide reductases, functions for metal processing, cofactor synthesis, electron donation, protein maturation and regulation. Most of the gene positions on the chromosome and locations relative to each other are not known. Only the genes encoding functions for nitrite respiration (nir) and nitric oxide (NO) respiration (nor) of denitrifiers depending on the cytochrome- $c d_{1}$ nitrite reductase seem to be preferentially organized in a mixed cluster comprising both the nir and nor genes (Jüngst et al., 1991a ; Braun \& 
Zumft, 1992; de Boer et al., 1994, 1996; Arai et al., 1995). In Pseudomonas stutzeri the nos genes for nitrousoxide $\left(\mathrm{N}_{2} \mathrm{O}\right)$ respiration are within $14 \mathrm{~kb}$ of the nir genes, forming a single denitrification cluster of about $30 \mathrm{~kb}$ (Braun \& Zumft, 1992); it is an open question whether this gene organization is representative of other denitrifiers. Here, we report the determination of the chromosomal map position of the principal denitrification genes of $P$. aeruginosa. A preliminary account of this work was given elsewhere (Vollack et al., 1996). The same set of probes was used for assignment of $P$. stutzeri genes to SpeI macrorestriction fragments.

\section{METHODS}

Bacterial strains and plasmids. $P$. aeruginosa PAO (DSM 1707) and the type strain (DSM 50071 ${ }^{\mathrm{T}}$ ) and $P$. stutzeri ZoBell (ATCC 14405) were grown at 37 and $30^{\circ} \mathrm{C}$, respectively. Luria-Bertani medium was used, with the addition of the following antibiotics ( $\mu \mathrm{g} \mathrm{ml}^{-1}$ ) where required: ampicillin $(100)$, chloramphenicol (30), streptomycin (200), tetracycline (10). Cells destined for agarose embedding and macrorestriction analysis were grown in $1 \%$ tryptone, $0.5 \% \mathrm{NaCl}$ $(\mathrm{pH} 7 \cdot 5)$ to the end of the exponential phase.

Gene probes. Table 1 lists the genes used in this study and the source organisms or plasmids providing them. If not stated otherwise, standard procedures were used (Sambrook et al., 1989). Plasmid DNA was isolated by alkaline cell lysis. Genomic DNA isolation followed a general protocol for Gram-negative bacteria (Chen \& Kuo, 1993). DNA fragments were recovered from agarose using the NucleoSpin kit (Macherey \& Nagel).

The following manipulations were done to obtain the various gene probes. Plasmid pPF028 with the anr gene region from $P$. aeruginosa PAO1 (Sawers, 1991) was cleaved by Bam $\mathrm{HI}$ and Pst I double digestion and subsequently with $D d e I$. The Bam HI-DdeI fragment carried the complete anr gene. The $a z u$ gene was amplified from genomic DNA of $P$. aeruginosa $\mathrm{PAO}$ (Meade et al., 1982) with primers derived from the sequence positions $573-593$ and $858-878$ (annealing temperature $53^{\circ} \mathrm{C}$ ) (Hoitink et al., 1990). A PCR fragment amplified from $P$. stutzeri genomic DNA and cloned into plasmid pMOS (Pharmacia) was used as the probe for $c c o N$. Its identity as the $c c o N$ gene was confirmed by sequencing. Degenerate primers were designed from the conserved loop region (KEYAEPEWY) connecting the transmembrane domains $\mathrm{V}$ and VI ( $5^{\prime} \mathrm{AAG}$ GARTACGCSGARCCGGARTGG 3') and a stretch from helix XI (TFEGPMM) (5' CATCATCGGRCCYTCGAAGGT 3') of several CcoN proteins (Preisig et al., 1993; de Gier et al., 1996; EMBL accession number U58092). The annealing temperature was $55^{\circ} \mathrm{C}$. The complete $f d x A$ gene was amplified from genomic DNA with the primers $5^{\prime}$ ACCTCGAGATGACCTTCGTSGTSACCGAC $3^{\prime}$ and $5^{\prime}$ TCGAATTCTAGCGYTCCAGGTACTGCAGCTTG 3' (annealing temperature $50^{\circ} \mathrm{C}$ ) derived from the amino acid sequence of $P$. stutzeri ferredoxin (Saeki et al., 1988). The added $5^{\prime}$ extensions introduced $X$ hol and EcoRI sites for cloning of the PCR product into pBluescript $\mathrm{SK}(-)$. Plasmid pANAP1 carries a napA fragment from Ralstonia eutropha (formerly Alcaligenes eutrophus) H16 (Siddiqui et al., 1993). The napA probe was excised together with 12 bp vector DNA by a double digestion with EcoRI and XbaI. Plasmid pSL962 carries the nar operon encoding respiratory nitrate reductase A from Escherichia coli (Sodergren \& DeMoss, 1988). Internal regions of narG and narH were isolated as 881 bp and 871 bp PstI fragments, respectively, and subcloned as pUC18 derivatives. The nar probes were cleaved by PstI. The intergenic region between the nos and nir clusters of $P$. stutzeri harbours a 1942 bp SmaI fragment carrying the nirE gene (Glockner \& Zumft, 1996). The fragment was cloned into pUC18 to give plasmid pUCS20.

Table 1. Characteristics of gene probes used for mapping

\begin{tabular}{|c|c|c|c|c|c|}
\hline Gene & Source organism & Plasmid or DNA & $\begin{array}{c}\text { Probe } \\
\text { size }(b p)^{*}\end{array}$ & $\begin{array}{c}\text { Hybridization } \\
\text { temperature }\left({ }^{\circ} \mathrm{C}\right) \dagger\end{array}$ & $\begin{array}{c}\text { Reference for } \\
\text { plasmid or gene }\end{array}$ \\
\hline anr & P. aeruginosa $\mathrm{PAO}$ & pPF028 & 940 & 60 & Sawers (1991) \\
\hline$a z u$ & P. aeruginosa $\mathrm{PAO}$ & Genomic DNA & 306 & 65,50 & Hoitink et al. (1990) \\
\hline $\operatorname{ccoN}$ & P. stutzeri ZoBell & Genomic DNA & 627 & 68,60 & Unpublished \\
\hline$f d x A$ & P. stutzeri ZoBell & Genomic DNA & 318 & 65 & Unpublished \\
\hline napA & R. eutropha $\mathrm{H} 16$ & pANAP1 & 998 & 42 & Siddiqui et al. (1993) \\
\hline narG & E. coli $\mathrm{K}-12$ & pSL962 & 881 & 55 & Sodergren \& DeMoss (1988) \\
\hline narH & E. coli K-12 & pSL962 & 871 & 55 & Sodergren \& DeMoss (1988) \\
\hline nirE & P. stutzeri ZoBell & pUCS20 & 497 & 65,60 & Glockner \& Zumft (1996) \\
\hline nirR & P. stutzeri ZoBell & pAJ206 & 268 & 65,50 & $\begin{array}{l}\text { Jüngst et al. (1991a); } \\
\text { unpublished }\end{array}$ \\
\hline nirs & P. stutzeri ZoBell & pNIR9 & 1200 & 60 & Jüngst et al. (1991b) \\
\hline nor $C B$ & P. stutzeri ZoBell & pNORCB1 & 1900 & 60 & Zumft et al. (1994) \\
\hline$n o s D$ & $P$. aeruginosa $a^{\mathrm{T}}$ & pBS-X & 285 & 65 & Zumft et al. (1992) \\
\hline $\operatorname{nos} R$ & P. aeruginosa ${ }^{\mathrm{T}}$ & pBS-E & 660 & 65 & Zumft et al. (1992) \\
\hline $\operatorname{nos} Z$ & P. stutzeri ZoBell & pNS220 & 1220 & 65 & Viebrock \& Zumft (1988) \\
\hline oprC & $P$. aeruginosa $^{\mathrm{T}}$ & Genomic DNA & 775 & 68,55 & Yoneyama \& Nakae (1996) \\
\hline $\operatorname{rpoN}$ & P. stutzeri ZoBell & Cosmid c167 & 999 & 65 & Unpublished \\
\hline
\end{tabular}

*Probes $a z u, c c o N, f d x A, \operatorname{nos} D$, nosR and oprC were labelled by PCR; the other probes were labelled by random priming.

tHybridization according to Engler-Blum et al. (1993), except for napA which was according to the Boehringer Mannheim protocol. 
Cleavage of pUCS20 by SmaI and BglII gave the nirE probe. The nirR gene was obtained from plasmid pAJ206, which was isolated from the Tn5 mutant MK206 of P. stutzeri (Jüngst $e t$ al., 1991a). A 2518 bp SmaI fragment was cloned into pUC18 to give pAJ610. By double digestion with PstI and SmaI an internal probe for nirR was prepared from pAJ610. The nirS probe was derived from plasmid pNIR9 (Jüngst et al., 1991a) by EcoRI and HindIII digestion together with 64 bp of flanking vector DNA. A $1.9 \mathrm{~kb}$ HindIII-BglII fragment of plasmid pNOR161 carrying the norCB operon of P. stutzeri (Braun \& Zumft, 1991) was initially cloned into M13mp18. nor $C B$ was subcloned as a HindIII-EcoRI fragment into pBR325 to give plasmid pNORCB1. The HindIII-EcoRI fragment served as the nor $C B$ probe. Plasmid pBS-X carries part of nos $Z$ from $P$. aeruginos $a^{T}$ together with the $5^{\prime}$ region of nosD ( $\mathrm{Zumft}$ et al., 1992). nosD was amplified and labelled by PCR with primers derived from the sequence positions 2395-2417 and 2680-2660. A probe for nosR was amplified from the plasmid pBS-E with the forward and reverse primers $5^{\prime}$ CTTCATCGGCTGGTATGCATTGG 3' and 5' GTCATCTGGCAGTCGAGGCAGTAG 3', respectively (unpublished sequence data). The annealing temperature for both nosD and nosR was $60^{\circ} \mathrm{C}$. The nos $Z$ probe of $P$. stutzeri was obtained as a Pst I digest from plasmid pNS220 (Zumft et al., 1992; Viebrock \& Zumft, 1988). The probe for the oprC gene was amplified and labelled by PCR (annealing temperature $60^{\circ} \mathrm{C}$ ) from genomic DNA of $P$. aeruginos $a^{\mathrm{T}}$ with primers derived from the published sequence positions 1242-1261 and 2016-1997 (Yoneyama \& Nakae, 1996). To identify the rpoN gene on cosmid $\mathrm{c} 167$ in a gene bank of $P$. stutzeri we used plasmid pNTR1, which includes a $3.4 \mathrm{~kb}$ Sall fragment carrying $r p o N$ from Pseudomonas putida (Köhler et al., 1989). The rpoN gene was cloned into pUC18, from which an internal $999 \mathrm{bp}$ $\mathrm{Xhol}$ fragment was isolated.

Most probes were non-radioactively labelled with a randompriming reaction kit using dUTP-digoxigenin and following the protocol of the supplier (Boehringer Mannheim). Reaction mixtures were incubated at $37^{\circ} \mathrm{C}$ for $24 \mathrm{~h}$ to increase the yield of label. Probes for $a z u, f d x A$, nosD, nosR and oprC were labelled by hot-start PCR (reagents from Perkin-Elmer) including $5 \%$ formamide to allow for the high GC content of pseudomonad DNA. The temperature programme consisted of 30 cycles each of $1 \mathrm{~min}$ at $95^{\circ} \mathrm{C}, 1 \mathrm{~min}$ at the annealing temperature specific for the probe, and $1 \mathrm{~min}$ at $72^{\circ} \mathrm{C}$; after the last cycle the mixture was kept for another $5 \mathrm{~min}$ at $72^{\circ} \mathrm{C}$. The extent of labelling was assayed by dot-blot analysis with commercially available DNA.

Physical mapping of genes. Genomic DNA of $P$. aeruginosa and $P$. stutzeri was prepared in small blocks of $1 \%$ low-gelling agarose type VII (Sigma) and cleaved in situ with SpeI or DpnI (Römling et al., 1994). DNA was separated by PFGE in a CHEF-DR II chamber (Bio-Rad) in $1.5 \%$ agarose (USB) at $10^{\circ} \mathrm{C}$ and $6 \mathrm{~V} \mathrm{~cm}^{-1}$. Three linearly increasing ramps of pulse intervals were applied for the SpeI digest: $8-50 \mathrm{~s}$ for $24 \mathrm{~h}$, $12-25 \mathrm{~s}$ for $22 \mathrm{~h}$ and $1-14 \mathrm{~s}$ for $14 \mathrm{~h}$. For the separation of $D p n I$ fragments, the $22 \mathrm{~h}$ ramp was modified to $12-35 \mathrm{~s}$. DNA thus separated was transferred to a Hybond- $\mathrm{N}+(0.45 \mu \mathrm{m})$ nylon membrane (Amersham) by the alkaline capillary method (Chomczynski, 1992). Detection of DNA was by chemiluminescence (Engler-Blum et al., 1993) and an anti-digoxigenin Fab fragment-alkaline phosphatase conjugate (Boehringer Mannheim). For double and triple hybridizations, the mixture of probes was adjusted to yield in most cases signals of comparable intensity. The probes for $c c o N$, nirE, nos $Z$ and $o p r C$ gave more than one band at low stringency. The signal persisting at the increased hybridization temperature was taken as specific for the gene under consideration.

\section{RESULTS AND DISCUSSION}

\section{Dispersion of denitrification genes on the chromosome of $P$. aeruginosa}

The $5.9 \mathrm{Mb}$ chromosome of $P$. aeruginosa is composed of 38 SpeI fragments (Römling \& Tümmler, 1991), of which 27, ranging from 40 to $517 \mathrm{~kb}$, were separated under the present conditions by one-dimensional PFGE. The probes derived from plasmids or strains specified in Table 1 were prepared as described in Methods and used for macrorestriction analysis of denitrification genes. Comparing the results of a SpeI digest with that of $D p n \mathrm{I}$ allowed the unequivocal assignment of genes used in the current study, mostly with an accuracy of $2 \mathrm{~min}$ on the chromosomal scale. Fig. 1 shows representative results obtained for hybridizing the SpeI digest with various gene probes. Genes were usually detected first by single hybridization, followed by double or triple hybridizations with gene combinations that assigned the hybridization signals unambiguously to fragments on the macrorestriction ladder. The genes anr (Ye et al.,

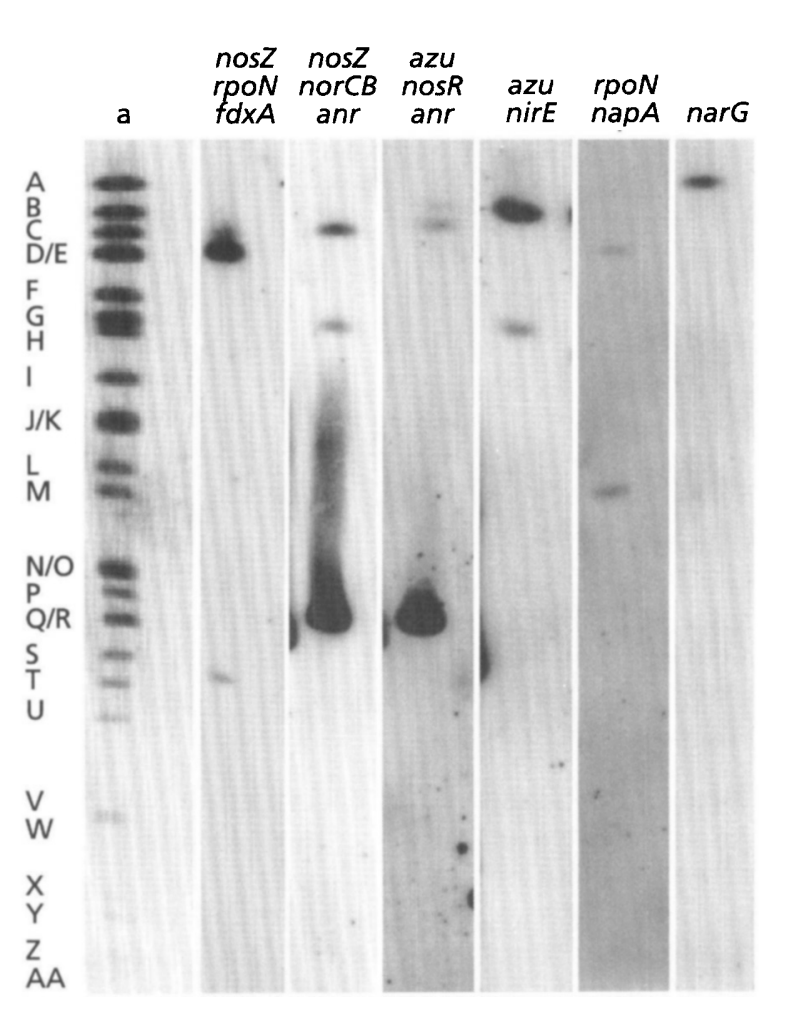

Fig. 1. Southern blot analysis of denitrification genes of a Spel digest of genomic DNA of $P$. aeruginosa PAO. Lane a shows the pattern of a Spel digest with fragment labels to the left. Gene probes are indicated above the lanes. For multiple hybridizations the order of the probe labels corresponds to the order of the signals below. Conditions for hybridization were as given in Table 1. 
Table 2. Localization of denitrification genes in P. aeruginosa PAO and P. stutzeri ZoBell

\begin{tabular}{|c|c|c|c|c|c|}
\hline \multirow[t]{2}{*}{ Gene } & \multirow[t]{2}{*}{ Gene product and/or function } & \multicolumn{2}{|c|}{$\begin{array}{l}P . \text { aeruginosa } \\
\text { restriction fragment }\end{array}$} & \multirow{2}{*}{$\begin{array}{c}\text { Gene } \\
\text { position } \\
(\min )\end{array}$} & \multirow{2}{*}{$\begin{array}{c}\text { Size of } \\
\text { P. stutzeri SpeI } \\
\text { fragment }(\mathrm{kb})\end{array}$} \\
\hline & & SpeI & DpnI & & \\
\hline$a n r(f n r A)$ & $\begin{array}{l}\text { FNR homologue, transcription } \\
\text { factor }\end{array}$ & $\mathrm{R}^{*}$ & $C^{*}$ & $57 \cdot 8-59 \cdot 7$ & 146 \\
\hline$a z u$ & $\begin{array}{l}\text { Azurin, presumed electron donor for } \\
\text { NirS }\end{array}$ & B & $\mathrm{J}_{2}$ & $4 \cdot 1-6 \cdot 7$ & No signal \\
\hline $\operatorname{ccoN}$ & $\begin{array}{l}\text { Catalytic subunit of the cytochrome- } \\
c b b_{3} \text { oxidase }\end{array}$ & $\mathrm{R}$ & $\mathrm{C}$ & $57 \cdot 8-59 \cdot 7$ & 146 \\
\hline$f d x A$ & $\begin{array}{l}\text { Ferredoxin, homologue of } \\
\text { Azotobacter Fd I }\end{array}$ & $\mathrm{T}$ & $\mathrm{H}$ & $30 \cdot 1-31 \cdot 0$ & 190 \\
\hline bem N† & $\begin{array}{l}\mathrm{O}_{2} \text {-independent } \\
\text { coproporphyrinogen-III oxidase }\end{array}$ & $\mathrm{R}$ & $\mathrm{C}$ & $57 \cdot 8-59 \cdot 7$ & 146 \\
\hline napA & $\begin{array}{l}\text { Periplasmic nitrate reductase, large } \\
\text { subunit }\end{array}$ & M & A & $61 \cdot 6-64 \cdot 2$ & 109 \\
\hline narG, narH & $\begin{array}{l}\text { Respiratory nitrate reductase, large } \\
\text { and small subunits }\end{array}$ & A & $\mathrm{H}$ & $27 \cdot 2-28 \cdot 4$ & 40 \\
\hline nirE & $\begin{array}{l}\text { Uroporphyrinogen III } \\
\text { methyltransferase }\end{array}$ & $\mathrm{H}$ & $\mathrm{F}_{1}$ & $19 \cdot 9-20 \cdot 5$ & 142 \\
\hline nirR & Product affects expression of nirS & \multicolumn{2}{|c|}{ No signal } & & 74 \\
\hline nirS & Cytochrome $c d_{1}$ nitrite reductase & $\mathrm{H} \ddagger$ & $F_{1}$ & $19 \cdot 9-20 \cdot 5$ & 142 \\
\hline nor $C B$ & NO reductase complex & $\mathrm{H}$ & $\mathrm{F}_{1}$ & $19 \cdot 9-20 \cdot 5$ & 142 \\
\hline$n o s D$ & $\begin{array}{l}\text { Product required for copper } \\
\text { insertion into NosZ }\end{array}$ & $\mathrm{C}$ & $\mathrm{N}$ & $33 \cdot 7-35 \cdot 8$ & 142 \\
\hline$n o s R$ & Putative regulator for nos $Z$ & $\mathrm{C}$ & $\mathrm{N}$ & $33 \cdot 7-35 \cdot 8$ & 142 \\
\hline$n o s Z$ & $\mathrm{~N}_{2} \mathrm{O}$ reductase & $\mathrm{C}$ & $\mathrm{N}$ & $33 \cdot 7-35 \cdot 8$ & 142 \\
\hline $\operatorname{oprC}(\operatorname{nos} A)$ & $\begin{array}{l}\text { Copper-containing outer-membrane } \\
\text { protein }\end{array}$ & A & $\mathrm{F}_{1}$ & $21 \cdot 8-24 \cdot 4$ & 103 \\
\hline$r p o N$ & Sigma factor $\sigma^{54}$ & $\mathrm{E} \$$ & IS & $71 \cdot 8-74 \cdot 9$ & 67 \\
\hline
\end{tabular}

" Mapped by Ye et al. (1995).

† Positions derived from comparative sequence analysis.

$\ddagger$ Mapped on fragment SpeI-H only (Holloway et al., 1994).

$\$$ Mapped by Farinha et al. (1993).

1995) and rpoN (Farinha et al., 1993) have been mapped previously and served as positive controls for our procedures. Table 2 summarizes the location of genes for denitrification for both sets of restriction fragments and the resulting positions on the chromosomal map of $P$. aeruginosa $\mathrm{PAO}$.

The probes narG and narH, encoding the catalytic $(\alpha)$ and small $(\beta)$ subunits of respiratory nitrate reductase, respectively, identified the same SpeI and $D p n I$ fragments. Genes for respiratory nitrate reductase, narGHJI, form an operon in nitrate-respiring bacteria, an organization that is anticipated also for $P$. aeruginosa. The nar genes are not linked to the denitrification genes sensu stricto. Many denitrifiers possess a third nitrate reductase in the form of a periplasmic dissimilatory-type enzyme. Thus far, evidence for this reductase has not been provided for the denitrifying pseudomonads. Using a $R$. eutropha napA probe that encodes the N-terminal part of the catalytic subunit of periplasmic nitrate reductase, we have identified a homologue of napA in $P$. aeruginosa (Fig. 1). The napA locus is not linked to the nar genes (Table 2).

We have previously identified the structural gene for nitrous-oxide $\left(\mathrm{N}_{2} \mathrm{O}\right)$ reductase, nos $Z$, of $P$. aeruginosa and established a nosRZD sequence (Zumft et al., 1992). As shown here, this locus is separate both from the nar and nir-nor loci (Fig. 1, Table 2), and organized differently from that of $P$. stutzeri, where the nos genes are within $\approx 14 \mathrm{~kb}$ of the nir locus. The product of a further nos gene, nos $A$, has been suggested to provide a $\mathrm{Cu}$-processing function for $\mathrm{N}_{2} \mathrm{O}$ reductase synthesis (Mokhele et al., 1987). The nosA gene encodes an outermembrane protein and was initially recognized from its property as a phage receptor of $P$. stutzeri JM300 (Clark et al., 1989). Until recently nosA had no known homologue in any other denitrifying bacterium. This situation has changed with the description of $o p r C$ from $P$. aeruginosa, whose product exhibits $65 \%$ sequence 
identity with NosA (Yoneyama \& Nakae, 1996). We have mapped $o p r C$ at $\approx 23 \mathrm{~min}$ at a separate locus from other denitrification genes (Table 2). In particular, the nosA homologue is not part of the nos gene cluster (see also below).

A functional denitrification apparatus depends on the expression of genes for haem $d_{1}$ biosynthesis. The first such gene, nirE, was found in Paracoccus denitrificans immediately downstream of nirS. The derived protein shows high similarity with methyltransferases acting on uroporphyrinogen III (de Boer et al., 1994). It has been an open question whether genes for haem $d_{1}$ biosynthesis are part of the nir region of $P$. aeruginosa. Our results show that nirE clusters with nirS and norCB. Previously, it had been deduced from sequencing that the vicinity of nirS harbours the genes encoding NO reductase and a regulator of the FNR family (Arai et al., 1995). During the preparation of this paper the $P$. aeruginosa sequence was extended downstream of nirS and revealed a gene cluster necessary for haem $d_{1}$ biosynthesis including nirE (Kawasaki et al., 1997). Two signals for nirE were detected in $P$. aeruginosa, which were associated with the SpeI-H fragment and the SpeI-D/E double band. On raising the hybridization temperature from 60 to $65^{\circ} \mathrm{C}$ the SpeI-H signal, which is part of the nir gene cluster, persisted. The signal not associated with the nir cluster is presumed to represent a distinct methyltransferase gene, for instance cysG or cobA, required for the biosynthesis of sirohaem and cobalamin, respectively.

Electron donors to $P$. aeruginosa nitrite reductase in vitro are cytochrome $c_{551}$ and the blue copper protein azurin, encoded by nirM and $a z u$, respectively. Whereas the gene for cytochrome $c_{551}$ is adjacent to nirS (Nordling et al., 1990), we found that the gene encoding azurin is not linked to a denitrification gene. Whether azurin has a physiological role at all in denitrification is still a matter of controversy and continuing investigation (Vijgenboom et al., 1995). Although the bacterial cell has the capability to subject unlinked genes to a common control mechanism, the absence of the $a z u$ gene from clusters of denitrification genes, together with the fact that it is not found consistently associated with denitrification (for instance $P$. stutzeri does not give a hybridization signal, see Table 2) casts doubt on an essential role for azurin in denitrification.

The anr gene encodes in $P$. aeruginosa a global regulator for anaerobic metabolism including the denitrification process (Galimand et al., 1991; Ye et al., 1995). anr maps at $\approx 59$ min independently from denitrification genes. We found that the $c c o N$ probe, encoding the catalytic subunit of the cytochrome- $c b b_{3}$ oxidase, detected the same fragment as the anr probe. Upstream of anr a sequence has been described that exhibits homology between $P$. stutzeri and $P$. aeruginosa (Cuypers $\&$ Zumft, 1993). A database search showed that the separate ORFs $\mathrm{A}$ and $\mathrm{B}$ of $P$. aeruginosa (EMBL accession number X57736) have to be joined and together represent the bem $N$ gene encoding the oxygenindependent coproporphyrinogen-III oxidase for the

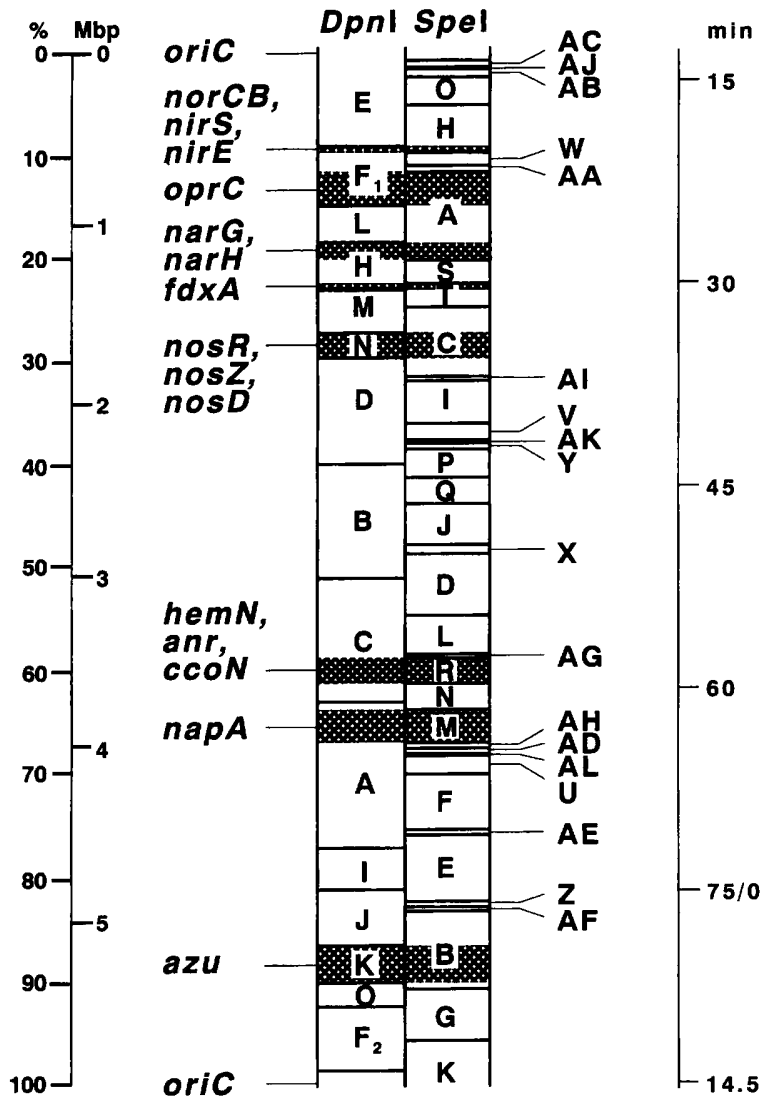

Fig. 2. Distribution of the loci for nitrogen oxide utilization on the chromosomal map of $P$. aeruginosa PAO. The map arrangement and map coordinates are derived from Holloway et al. (1994).

anaerobic biosynthesis of protohaem (EMBL accession number X97981).

Fig. 2 shows a linear representation of the $P$. aeruginosa chromosome with the results of this study. Genes for denitrification are concentrated in the $20-36 \mathrm{~min}$ segment of the chromosome. They are distributed in three regions harbouring the genes for nitrite and $\mathrm{NO}$ reduction at $\approx 20 \mathrm{~min}$, separate from those for nitrate reduction at $\approx 28 \mathrm{~min}$ and $\mathrm{N}_{2} \mathrm{O}$ reduction at $\approx 34 \mathrm{~min}$. The periplasmic nitrate reductase system, nap, constitutes a further locus at $\approx 63 \mathrm{~min}$. In their dispersion over a large part of the chromosome, denitrification genes form an intrinsic part of the overall genome organization of $P$. aeruginosa and not an accessory trait that is transferable as a 'dentrification island' among prokaryotes. We have previously argued that denitrification can be considered as the modular assembly of at least three respiratory processes utilizing nitrate, nitrite and nitrous oxide (Zumft, 1997).

Several other loci associated with nitrate utilization, but functionally poorly defined, have been mapped by classical techniques (see Holloway et al., 1994). Given the precision of conjugational mapping, the loci nir$9006(21 \mathrm{~min})$ and $n a r-9001(30 \mathrm{~min})$ are close enough to 


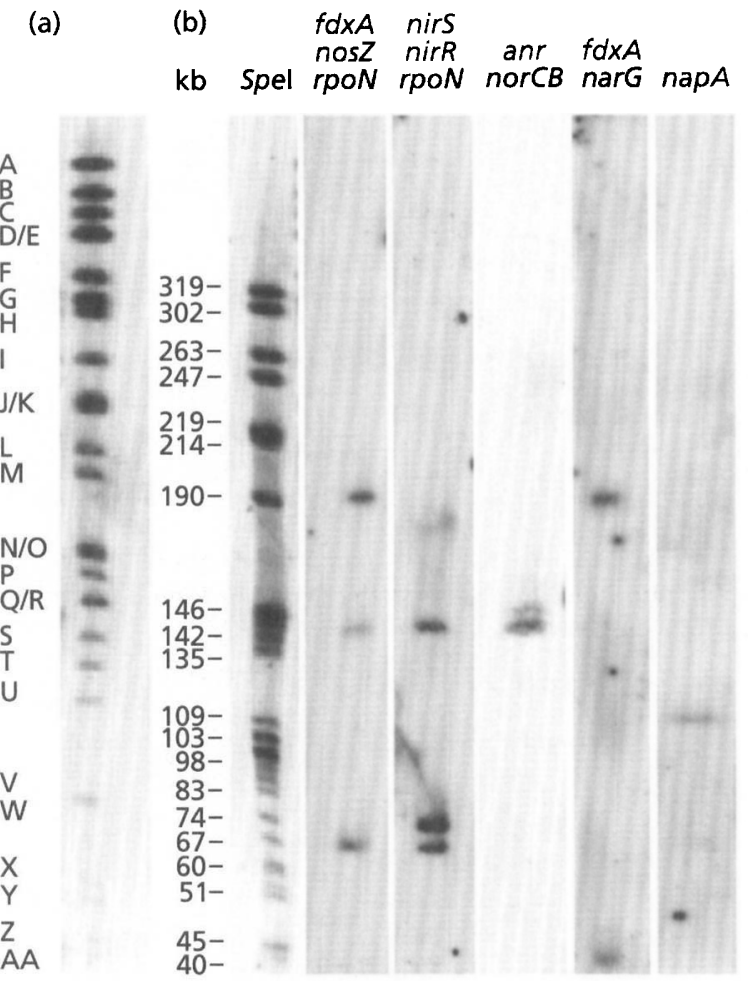

Fig. 3. Localization of denitrification genes on macrorestriction fragments of $P$. stutzeri ZoBell. (a) Spel digest of $P$. aeruginosa used for size calibration; (b) Spel pattern of genomic DNA from $P$. stutzeri and Southern blot results with the gene probes indicated above the lanes. Conditions for hybridization were as given in Table 1.

the nirS and narGH loci, respectively, to make identity likely. For narD, a role in molybdenum transport or processing for nitrate reductase is suggested since the respective gene defect is suppressed by a high dose of molybdate (van Hartingsveldt \& Stouthamer, 1973).

\section{Localization of denitrification genes on Spel macrorestriction fragments of $\boldsymbol{P}$. stutzeri}

We have also used SpeI to restrict genomic DNA of $P$. stutzeri ZoBell and assigned the gene probes of Table 1 to individual fragments. The $P$. stutzeri fragments were calibrated using the SpeI ladder of $P$. aeruginosa. We found 25 fragments, ranging in size from 40 to $319 \mathrm{~kb}$, at least six of which consisted of overlapping multiple fragments (Fig. 3). The sum of the SpeI fragments, accounting for putative double bands, extrapolated to a genome size of $\approx 3.8 \mathrm{Mb}$ for $P$. stutzeri ZoBell. Restriction of DNA with CeuI, however, yields only four fragments totalling $4.3 \mathrm{Mb}$ (Ginard et al., 1997) and implies a somewhat higher number of SpeI fragments.

FnrA is the homologue in $P$. stutzeri of the $P$. aeruginosa regulator ANR. However, unlike ANR, FnrA does not affect denitrification directly. The fnrA gene is located in $P$. stutzeri on the $146 \mathrm{~kb}$ SpeI fragment which also reacts positively with the $c c o N$ probe (Table 2). Sequencing of this region showed that $h e m N, f n r A$ and $c c o N$ are linked (unpublished data). The denitrification gene cluster in $P$. stutzeri was located, using nirS and nos $Z$ as indicators, on a $142 \mathrm{~kb}$ SpeI fragment. The nar $G$ operon was found on the smallest SpeI fragment of $40 \mathrm{~kb}$. napA was located on the $109 \mathrm{~kb}$ SpeI fragment. Given the evidence from $P$. aeruginosa, it is likely that these loci are not linked with the $30 \mathrm{~kb}$ denitrification cluster of P. stutzeri (Fig. 3, Table 2).

The oprC gene (nosA homologue) was detected in P. stutzeri ZoBell on the $103 \mathrm{~kb}$ SpeI fragment (hybridization temperature $55^{\circ} \mathrm{C}$ ). The role of the NosA/OprC proteins in $\mathrm{Cu}$ homoeostasis and/or $\mathrm{N}_{2} \mathrm{O}$ reductase biosynthesis of the pseudomonads is still insufficiently established (Lee et al., 1991; Yoneyama \& Nakae, 1996). The mutational absence of NosA in P. stutzeri JM300 is associated with the formation of an enzymically inactive $\mathrm{N}_{2} \mathrm{O}$ reductase that lacks copper (Mokhele et al., 1987). NosA of P. stutzeri and OprC of $P$. aeruginosa both form voltage-gated outer-membrane channels with a slight preference for $\mathrm{Cu}$; the binding of one to three $\mathrm{Cu}$ atoms has been reported. The synthesis of NosA/OprC is repressed if the $\mathrm{Cu}$ concentration in the medium is above $10 \mu \mathrm{M}$. A limited sequence similarity has been observed between NosA/OprC and TonB-dependent outer-membrane receptors for siderophores or vitamin $B_{12}$. NosA, it was hypothesized, may be part of a $\mathrm{Cu}$ ion or $\mathrm{Cu}$ chelate uptake system (Lee et al., 1991).

$n i r R$ represents a novel gene whose identification is thus far limited to $P$. stutzeri. It affects the expression level of $n i r S$ and nitrite reduction activity (Jüngst $e t$ al., 1991a). The gene is located outside the denitrification gene cluster and encodes a protein of $25 \cdot 6 \mathrm{kDa}$ that has no noteworthy similarity with known proteins in databases (unpublished results). The gene probe did not give a signal with $P$. aeruginosa DNA.

The expression of denitrification genes may require an alternative sigma factor for which $\sigma^{54}$ is a candidate. The $r p o N$ gene is located on a $67 \mathrm{~kb}$ Spel fragment in P. stutzeri. Azotobacter ferredoxin I has been proposed to be involved in the oxidative stress response mediated by the sox regulon (Yannone \& Burgess, 1997), and a similar role is feasible for the pseudomonads. $f d x A$ of $P$. stutzeri encodes a 7-Fe low-potential ferredoxin that is homologous to Azotobacter vinelandii ferredoxin I (Saeki et al., 1988). The $f d x A$ locus maps separately from other denitrification loci (Table 2). The $f d x A$ gene is of importance to denitrification since the sox regulon is also activated by nitric oxide (Nunoshiba et al., 1993) and the sox system may be part of a defence mechanism against $\mathrm{NO}$ in denitrifiers.

\section{ACKNOWLEDGEMENTS}

We are indebted to J. A. DeMoss, B. Friedrich, S. Harayama, G. Sawers and R. A. Siddiqui for providing plasmids. We thank K. Schmidt for helpful advice. The work was supported 
by the Deutsche Forschungsgemeinschaft and Fonds der Chemischen Industrie.

\section{REFERENCES}

Arai, H., Igarashi, Y. \& Kodama, T. (1995). Expression of the nir and nor genes for denitrification in Pseudomonas aeruginosa requires a novel CRP/FNR-related transcriptional regulator, DNR, in addition to ANR. FEBS Lett 371, 73-76.

de Boer, A. P. N., Reijnders, W. N. M., Kuenen, J. G., Stouthamer, A. H. \& van Spanning, R. J. M. (1994). Isolation, sequencing and mutational analysis of a gene cluster involved in nitrite reduction in Paracoccus denitrificans. Antonie Leeuwenhoek 66, 111-127.

de Boer, A. P. N., van der Oost, J., Reijnders, W. N. M., Westerhoff, H. V., Stouthamer, A. H. \& van Spanning, R. J. M. (1996). Mutational analysis of the nor gene cluster which encodes nitricoxide reductase from Paracoccus denitrificans. Eur J Biochem 242, 592-600.

Braun, C. \& Zumft, W. G. (1991). Marker exchange of the structural genes for nitric oxide reductase blocks the denitrification pathway of Pseudomonas stutzeri at nitric oxide. J Biol Chem 266, 22785-22788.

Braun, C. \& Zumft, W. G. (1992). The structural genes of the nitric oxide reductase complex from Pseudomonas stutzeri are part of a 30-kilobase gene cluster for denitrification. J Bacteriol 174, 2394-2397.

Chen, W. \& Kuo, T. (1993). A simple and rapid method for the preparation of gram-negative bacterial genomic DNA. Nucleic Acids Res 21, 2260.

Chomczynski, P. (1992). One-hour downward alkaline capillary transfer for blotting of DNA and RNA. Anal Biochem 201, 134-139.

Clark, M. A., Tang, Y. J. \& Ingraham, J. L. (1989). A NosA-specific bacteriophage can be used to select denitrification-defective mutants of Pseudomonas stutzeri. J Gen Microbiol 135, 2569-2575.

Cuypers, H. \& Zumft, W. G. (1993). Anaerobic control of denitrification in Pseudomonas stutzeri escapes mutagenesis of an fnr-like gene. J Bacteriol 175, 7236-7246.

Engler-Blum, G., Meier, M., Frank, J. \& Müller, G. A. (1993). Reduction of background problems in non-radioactive Northern and Southern blot analyses enables higher sensitivity than ${ }^{32} \mathrm{P}$ based hybridizations. Anal Biochem 210, 235-244.

Farinha, M. A., Ronald, S. L., Kropinski, A. M. \& Paranchych, W. (1993). Localization of the virulence-associated genes $p i l A, p i l R$, $r p o N$, fliA, fliC, ent, and $f b p$ on the physical map of Pseudomonas aeruginosa PAO1 by pulsed-field electrophoresis. Infect Immun 61, 1571-1575.

Galimand, M., Gamper, M., Zimmermann, A. \& Haas, D. (1991). Positive FNR-like control of anaerobic arginine degradation and nitrate respiration in Pseudomonas aeruginosa. J Bacteriol 173, 1598-1606.

de Gier, J.-W. L., Schepper, M., Reijnders, W. N. M. \& 9 other authors (1996). Structural and functional analysis of $a a_{3}$-type and $c b b_{3}$-type cytochrome $c$ oxidases of Paracoccus denitrificans reveals significant differences in proton-pump design. Mol Microbiol 20, 1247-1260.

Ginard, M., Lalucat, J., Tümmler, B. \& Römling, U. (1997). Genome organization of Pseudomonas stutzeri and resulting taxonomic and evolutionary considerations. Int J Syst Bacteriol 47, 132-143.

Glockner, A. B. \& Zumft, W. G. (1996). Sequence analysis of an internal $9 \cdot 72-\mathrm{kb}$ segment from the $30-\mathrm{kb}$ denitrification gene cluster of Pseudomonas stutzeri. Biochim Biophys Acta 1277, 6-12.

van Hartingsveldt, J. \& Stouthamer, A. H. (1973). Mapping and characterization of mutants of Pseudomonas aeruginosa affected in nitrate respiration in aerobic or anaerobic growth. $J$ Gen Microbiol 74, 97-106.

Hoitink, C. W. G., Woudt, L. P., Turenhout, J. C. M., van de Kamp, M. \& Canters, G. W. (1990). Isolation and sequencing of the Alcaligenes denitrificans azurin-encoding gene: comparison with the genes encoding blue copper proteins from Pseudomonas aeruginosa and Alcaligenes faecalis. Gene 90, 15-20.

Holloway, B. W., Römling, U. \& Tummler, B. (1994). Genomic mapping of Pseudomonas aeruginosa PAO. Microbiology 140, 2907-2929.

Jeter, R. M., Sias, S. R. \& Ingraham, J. L. (1984). Chromosomal location and function of genes affecting Pseudomonas aeruginosa nitrate assimilation. J Bacteriol 157, 673-677.

Jüngst, A., Braun, C. \& Zumft, W. G. (1991a). Close linkage in Pseudomonas stutzeri of the structural genes for respiratory nitrite reductase and nitrous oxide reductase, and other essential genes for denitrification. Mol Gen Genet 225, 241-248.

Jüngst, A., Wakabayashi, S., Matsubara, H. \& Zumft, W. G. (1991b). The nirSTBM region coding for cytochrome $c d_{1^{-}}$ dependent nitrite respiration of Pseudomonas stutzeri consists of a cluster of mono-, di-, and tetraheme proteins. FEBS Lett 279, 205-209.

Kawasaki, S., Arai, H., Kodama, T. \& Igarashi, Y. (1997). Gene cluster of dissimilatory nitrite reductase (nir) from Pseudomonas aeruginosa: sequencing and identification of a locus for heme $d_{1}$ biosynthesis. J Bacteriol 179, 235-242.

Köhler, T., Harayama, S., Ramos, J.-L. \& Timmis, K. N. (1989). Involvement of Pseudomonas putida RpoN sigma factor in regulation of various metabolic functions. J Bacteriol 171, 4326-4333.

Lee, H. S., Abdelal, A. H. T., Clark, M. A. \& Ingraham, J. L. (1991). Molecular characterization of nosA, a Pseudomonas stutzeri gene encoding an outer membrane protein required to make coppercontaining $\mathrm{N}_{2} \mathrm{O}$ reductase. $J$ Bacteriol 173, 5406-5413.

Liao, X., Charlebois, I., Ouellet, C. \& 9 other authors (1996). Physical mapping of 32 genetic markers on the Pseudomonas aeruginosa PAO1 chromosome. Microbiology 142, 79-86.

Meade, H. M., Long, S. R., Ruvkun, G. B., Brown, S. E. \& Ausubel, F. M. (1982). Physical and genetic characterization of symbiotic and auxotrophic mutants of Rhizobium meliloti induced by transposon Tn5 mutagenesis. J Bacteriol 149, 114-122.

Mokhele, K., Tang, Y. J., Clark, M. A. \& Ingraham, J. L. (1987). A Pseudomonas stutzeri outer membrane protein inserts copper into $\mathrm{N}_{2} \mathrm{O}$ reductase. J Bacteriol 169, 5721-5726.

Nordling, M., Young, S., Karlsson, B. G. \& Lundberg, L. G. (1990). The structural gene for cytochrome $c_{551}$ from Pseudomonas aeruginosa: the nucleotide sequence shows a location downstream of the nitrite reductase gene. FEBS Lett 259, 230-232.

Nunoshiba, T., deRojas-Walker, T., Wishnok, J. S., Tannenbaum, S. R. \& Demple, B. (1993). Activation by nitric oxide of an oxidative-stress response that defends Escherichia coli against activated macrophages. Proc Natl Acad Sci USA 90, 9993-9997.

Preisig, O., Anthamatten, D. \& Hennecke, H. (1993). Genes for a microaerobically induced oxidase complex in Bradyrhizobium japonicum are essential for a nitrogen-fixing endosymbiosis. Proc Natl Acad Sci USA 90, 3309-3313.

Römling, U. \& Tümmler, B. (1991). The impact of two-dimensional pulsed-field gel electrophoresis techniques for the consistent and 
complete mapping of bacterial genomes: refined physical map of Pseudomonas aeruginosa PAO. Nucleic Acids Res 19, 3199-3206.

Römling, U., Heuer, T. \& Tummler, B. (1994). Bacterial genome analysis by pulsed field gel electrophoresis techniques. Adv Electrophor 7, 355-405.

Saeki, K., Wakabayashi, S., Zumft, W. G. \& Matsubara, H. (1988). Pseudomonas stutzeri ferredoxin: close similarity to Azotobacter vinelandii and Pseudomonas ovalis ferredoxins. J Biochem 104, 242-246.

Sambrook, J., Fritsch, E. F. \& Maniatis, T. (1989). Molecular Cloning: a Laboratory Manual, 2nd edn. Cold Spring Harbor, NY: Cold Spring Harbor Laboratory.

Sawers, R. G. (1991). Identification and molecular characterization of a transcriptional regulator from Pseudomonas aeruginosa $\mathrm{PAO} 1$ exhibiting structural and functional similarity to the FNR protein of Escherichia coli. Mol Microbiol 5, 1469-1481.

Sias, S. R., Stouthamer, A. H. \& Ingraham, J. L. (1980). The assimilatory and dissimilatory nitrate reductases of Pseudomonas aeruginosa are encoded by different genes. J Gen Microbiol 118, 229-234.

Siddiqui, R. A., Warnecke-Eberz, U., Hengsberger, A., Schneider, B., Kostka, S. \& Friedrich, B. (1993). Structure and function of a periplasmic nitrate reductase in Alcaligenes eutrophus H16. $J$ Bacteriol 175, 5867-5876.

Sodergren, E.J. \& DeMoss, J. A. (1988). narI region of the Escherichia coli nitrate reductase (nar) operon contains two genes. J Bacteriol 170, 1721-1729.

Viebrock, A. \& Zumft, W. G. (1988). Molecular cloning, heterologous expression, and primary structure of the structural gene for the copper enzyme nitrous oxide reductase from denitrifying Pseudomonas stutzeri. J Bacteriol 170, 4658-4668.

Vijgenboom, E., Busch, J. E. \& Canters, G. W. (1995). Physiological role and expression of the blue copper protein azurin in Pseudomonas aeruginosa. J Inorg Biochem 59, 720.

Vollack, K.-U., Römling, U. \& Zumft, W. G. (1996). Mapping of denitrification genes from Pseudomonas aeruginosa by macrorestriction analysis. Biospectrum 1996, 70 (abstract).

Yannone, S. M. \& Burgess, B. K. (1997). Identification of a palindromic sequence that is responsible for the up-regulation of NADPH-ferredoxin reductase in a ferredoxin I deletion strain of Azotobacter vinelandii. J Biol Chem 272, 14454-14458.

Ye, R. W., Haas, D., Ka, J.-O., Krishnapillai, V., Zimmermann, A., Baird, C. \& Tiedje, J. M. (1995). Anaerobic activation of the entire denitrification pathway in Pseudomonas aeruginosa requires Anr, an analog of Fnr. J Bacteriol 177, 3606-3609.

Yoneyama, H. \& Nakae, T. (1996). Protein C (OprC) of the outer membrane of Pseudomonas aeruginosa is a copper-regulated channel protein. Microbiology 142, 2137-2144.

Zumft, W. G. (1997). Cell biology and the molecular basis of denitrification. Microbiol Mol Biol Rev 61, 533-616.

Zumft, W. G., Dreusch, A., Löchelt, S., Cuypers, H., Friedrich, B. \& Schneider, B. (1992). Derived amino acid sequences of the nos $Z$ gene (respiratory $\mathrm{N}_{2} \mathrm{O}$ reductase) from Alcaligenes eutrophus, Pseudomonas aeruginosa and Pseudomonas stutzeri reveal potential copper-binding residues: implications for the $\mathrm{Cu}_{\mathrm{A}}$ site of $\mathrm{N}_{2} \mathrm{O}$ reductase and cytochrome- $c$ oxidase. Eur J Biochem 208, $31-40$.

Zumft, W. G., Braun, C. \& Cuypers, H. (1994). Nitric oxide reductase from Pseudomonas stutzeri: primary structure and gene organization of a novel bacterial cytochrome $b c$ complex. Eur J Biochem 219, 481-490.

Received 10 July 1997; revised 19 September 1997; accepted 2 October 1997. 